\title{
Comments on "Billy Sunday and the Mystique of the Middle West"
}

EDITOR'S NOTE: The preceding article is not typical of the kind of articles that usually appear in the Annals of Iowa. Rather than focusing narrowly on a particular development in Iowa history and constructing an argument that is closely tied to a distinct body of readily identifiable evidence, Robert Martin courageously ventures a sweeping interpretation of the connections between large-scale developments in the history of the Midwest and the career of one of its most famous - or infamous - sons.

Billy Sunday is usually regarded by those who know of him as either a saint or a charlatan. But Robert Martin has found, as most good historians do when they look closely at apparently simple stories, that Sunday's career is much more complex than either his admirers or critics recognize. Martin's essay is intended to encourage readers to think about Sunday in a different way - to go beyond the dramatic quality of Sunday's evangelism to consider the ways in which the man and his career resonated with the hopes and fears of early twentieth-century Americans.

Because Martin's goal is to provoke reflection rather than to "prove" a point, I thought it would be useful for rea-ers to have the opportunity to see what kinds of thoughts the essay stimulated among a couple of historians. Mark Noll and Riindall Balmer responded to my invitation to share with readers their thoughts upon reading Martin's essay. Asking "What does this provocative essay do specifically for the history of Iowa?" Noll suggests some possibilities for turning Martin's hypotheses into an agenda for possible future research. Balmer takes up Martin's notion of Sunday as someone who captured the tensions in an age of transition and shows how that is part of a long tradition - both before and after Sunday's career - among American re- 
vivalists. I hope Noll and Balmer's reflections - in conjunction with Martin's thought-provoking essay - will encourage all readers to raise new questions and gain new insights into the meaning of the history of Iowa and the Midwest.

\section{Linking Billy Sunday and the Mystique of the Middle West to the Religious History of Iowa}

\section{MARK A. NOLL}

IN HIS CREATIVE THINK PIECE, Robert Martin argues that it is possible to link the rise and decline of Billy Sunday as a popular revivalist to a parallel rise and decline of the image of the Midwest - from a Progressive, optimistic, dynamic place to one marked by parochialism, insularity, and rural backwardness. Such an argument cannot, of course, be "demonstrated" in any strict sense. But Martin's arguments are especially suggestive at several points - for example, in contending that Sunday's "athleticism, masculinity, and Christianity" resembled virtues praised by the era's political Progressives; or in showing that Sunday's revival message combined traditional themes of Protestant Christianity with more contemporary injunctions about an up-to-date American moralism. There is, thus, some reason to think that the rising tide of popularity that Sunday enjoyed through the First World War should be regarded as a national seal of approval for a Progressive, Protestant, midwestern style and that the descending curve of popularity that Sunday experienced from about 1920 was a sign that this style was going out of favor. For its provocations to think about big ideas and national trends in connection with one flamboyant career, Martin's essay performs a genuine service. But does it do anything specifically for the history of Iowa?

Beyond noting that Sunday was born in Story County, that he lived for a time in an Iowa orphanage, and that he later worked in Nevada and Marshalltown before pursuing his 
Copyright of Annals of Iowa is the property of State of Iowa, by \& through the State Historical Society of Iowa and its content may not be copied or emailed to multiple sites or posted to a listserv without the copyright holder's express written permission. However, users may print, download, or email articles for individual use. 